\title{
The Growth in Military Expenditure in Germany 1951-2011: Did Parties Matter?
}

\author{
Björn Kauder \\ Niklas Potrafke
}

CESIFO WORKING PAPER NO. 5337

CAtegory 2: Public Choice

APRIL 2015

An electronic version of the paper may be downloaded

- from the SSRN website:

- from the RePEc website:

- from the CESifo website:

wWw.SSRN.com

Www.RePEc.org

www.CESifo-group.org/wp 


\title{
The Growth in Military Expenditure in Germany 1951-2011: Did Parties Matter?
}

\begin{abstract}
We examine whether government ideology was correlated with the growth in military expenditure in Germany over the period 1951-2011. By using various measures of government ideology, the results do not show any effect. The exception is an ideology measure based on the Comparative Manifesto Project (Left-Right scale): using this measure, the results show that the growth in military expenditure increased by about 2.4 percentage points, when the ideology variable (right-wing) increased by one standard deviation. This effect, however, is based on observations until the early 1960s and cannot be generalized. The major political parties agreed on how to evaluate international risks and threats. Government ideology retired to the background. We conjecture that the consensus among the major parties will persist - even if military spending needs to be increased in response to new international risks and threats.
\end{abstract}

JEL-Code: D720, H000.

Keywords: military expenditure, partisan politics, economic policy-making, Germany.

Björn Kauder

Ifo Institute - Leibniz Institute for

Economic Research

at the University of Munich

Poschingerstrasse 5

Germany-81679 Munich

kauder@ifo.de
Niklas Potrafke

Ifo Institute - Leibniz Institute for

Economic Research

at the University of Munich

Poschingerstrasse 5

Germany - 81679 Munich

potrafke@ifo.de

24 April 2015

This paper has been accepted for publication in Defence and Peace Economics. 


\section{Introduction}

Economic theories suggest that government ideology is correlated with military expenditure. The partisan approaches claim that left-wing governments pursue more expansionary economic policies than right-wing governments (Hibbs 1977; Alesina 1987). Expansionary economic policies include a large size of government. Left-wing governments may thus also endorse military expenditure, especially when they recruit additional military personnel and employees who are not competitive in the labour market. By recruiting non-competitive employees or reintegrating unemployed individuals in the labour market, left-wing governments gratify their constituencies. ${ }^{1}$ By contrast, right-wing governments and their electorates tend to endorse security and support the hierarchies and discipline that are associated with armed forces. In a similar vein, right-wing governments advocate interventionist (hawkish) or even imperialist foreign policies, and left-wing governments advocate dovish foreign policies (see Whitten and Williams 2011). The extent to which government ideology is correlated with military expenditure thus remains an undetermined empirical question.

Empirical studies examining how government ideology is correlated with military expenditure arrive at ambiguous conclusions. Bove et al. (2014) used data for 22 OECD countries over the 1988-2009 period. The results show that growth in military expenditure was higher under right-wing governments. Using panel data for 23 OECD countries over the 1970-1997 period and 20 OECD countries over the 1990-2006 period, the results of Potrafke (2011) do not suggest any effect of government ideology on growth in military expenditure. Whitten and Williams (2011) put a question mark over the left-right scale. Using panel data for 19 industrialized countries (including Turkey) over the 1952-1997 period, the results show

\footnotetext{
${ }^{1}$ Tridimas (2015) describes that in ancient Athens, war meant redistribution benefitting the poor at the expense of the rich who bore a disproportionate burden of the war. Governments may well increase military expenditure to stimulate the economy ('Military Keynesianism'; see, for example, Griffin et al. 1982).
} 
that hawkish governments and governments that endorse the welfare state increased military expenditure. $^{2}$

It is conceivable that previous panel-data studies did not show strong ideologyinduced effects because in European countries 'there is very little uniformity in the factors that determine each country’s demand for military expenditure’ (Nikolaidou 2008, 273). In particular, government ideology is an excellent case in point. Single-country studies have shown that in countries such as Greece and Sweden military expenditure was somewhat higher under left-wing governments, while in the United Kingdom, the Netherlands, and Turkey military expenditure was higher under right-wing governments and legislatures. Evidence for the United States is mixed (see Kollias and Paleologou 2003; Eichenberg and Stoll 2003; Karagol and Turhan 2008; Dalen and Swank 1996; Wlezien 1996; Nincic and Cusack 1979; Correa and Kim 1992).

We examine how government ideology was correlated with the growth in military expenditure in Germany. There have been three previous studies referring to that issue. ${ }^{3}$ Eichenberg and Stoll (2003) used data from the late 1960s until 1998 and show that the change in military expenditure was somewhat lower, the higher the percentage of conservative legislatures. The authors proposed that the social-democratic chancellor Helmut Schmidt (in office 1974-1982) was one of the left-wing 'proponents of a strong defense - or at least proponents of a balanced commitment to defense and negotiation'. Moreover: '... that the end of the cold war and the consequent reductions in defense spending occurred in some prominent cases under Conservatives: ... Kohl ...' (p. 413). Maneval (1994) used data over the 1960-1990 period, included ‘a dummy-variable for the change of coalition’ and concluded that 'the political variable practically does not help to explain the volume of West German defense expenditure; from this can be concluded that during the Cold War a broad consensus

\footnotetext{
${ }^{2}$ Strauss (2015) examines whether government ideology influences arms races.

${ }^{3}$ Bayer and Naunheim (2014) describe how German military expenditure is composed, but do not relate to government ideology.
} 
on defense policy existed among the governing parties' (p. 239). Potrafke (2009a) examined whether government ideology was correlated with budget composition over the 1951-2003 period. The results do not show that government ideology was correlated with growth in military expenditure (as measured in percent of GDP).

An issue is whether the correlation between growth in military expenditure and government ideology depends on the time period examined and the empirical strategies employed. We use data over the period 1950-2011 and various government ideology measures to reexamine the nexus between growth in military expenditure and government ideology.

Examining German military expenditure in a single-country study is a worthwhile endeavour because Germany initiated the Second World War, and involving German forces in any military conflict has been a big issue ever since. 'Germany's aversion to the use of force and its embrace of multilateralism is a reaction to the country's past. As one of Germany's eminent scholars on the subject argued, the "first lesson drawn from the Nazi period was a widespread, instinctive pacifism, a rejection of anything military and of any use of force.”’ (Giegerich 2003, 4). Elaborating on the mission of the North Atlantic Treaty Organization (NATO) in Afghanistan, Auerswald and Saideman (2014, 22) write: 'It is impossible to discuss German behaviour in Afghanistan, for instance, without considering the weight of the past upon the present day: the pacifism produced by the World War II experience, the reluctance to kill or suffer causalities, and that the German military may have rules and procedures that are directly derived from these experiences.' The country's past influences any kind of policy-making since 1945 (the European debt crisis is a case in point when protestors in southern European countries showed images of Adolf Hitler). Military conflict is especially controversial. To be sure, the country’s past did not prevent any German militarization. By contrast, during the Cold War, western allies such as the United States supported Germany in guarding its Eastern border against Soviet aggressions: ‘...the European security interests with regard to the threat from the East (the thesis being that defence in Central Europe was 
only possible with the help of West German troops) prevailed...' (Maneval 1994, 222). Germany joined the NATO in 1955. Holding off forces in military conflicts notwithstanding, Germany did not free-ride on NATO burdens (see, for example, Olson and Zeckhauser 1966; Sandler and Forbes 1980; Solomon 2004; Sandler and Shimizu 2014).

\section{Data and Descriptive Statistics}

We use data from the German Federal Statistical Office for military expenditure and GDP from 1950-1990 for former West Germany and from 1991-2011 for reunified Germany. Table 1 shows descriptive statistics and data sources.

Government ideology is measured by different variables: an ideology index distinguishing between left-wing, center, and right-wing governments, the index of Bjørnskov (2008a), and ideology indices based on the Comparative Manifesto Project (CMP) of Budge et al. (2001), Klingemann et al. (2006), and Volkens et al. (2014). We describe the indices of Bjørnskov (2008a) and the CMP data, and descriptive statistics using these indices below.

The differences between left-wing and right-wing governments will be tested on the left-right scale using the variable Left and, in an alternative specification, by using different coalition type dummies. The dummy variable Left takes on the value 1 when a left-wing, 0.5 when a center (grand coalition), and 0 when a right-wing government was in office. Distinguishing left-wing, center, and right-wing governments by using this variable corresponds to measuring government ideology as proposed, for example, by Budge et al. (1993) and Woldendorp et al. (1998, 2000) and employed by Potrafke (2009b). Alternatively, the coalition type dummy variables take on the value 1 when the considered coalition type was in power and 0 otherwise. We distinguish between four different coalition types that governed at the German federal level: CDU/CSU/FDP (right-wing), SPD/FDP (left-wing), SPD/Greens (left-wing), and CDU/CSU/SPD (center; reference category). 
Figures 1 and 2 show military expenditure (in percent of GDP) and the growth rate in military expenditure (in percent of GDP) from 1950/1951 until 2011. The vertically shaded areas describe the type of government: white is a left-wing government, light grey is a center government, and dark grey is a right-wing government. The individual coalition parties are displayed in the top of the bars. In 1950, military expenditure accounted for $4.83 \%$ of GDP. In 1967, after the grand coalition of CDU/CSU (Christian Democratic/Social Union) and SPD (Social Democratic Party) had succeeded the right-wing government of CDU/CSU and FDP (Free Democratic Party), military expenditure totalled 4.25\% of GDP. In autumn 1969, the left-wing SPD/FDP government was elected to office. Over the 1970-1982 period, military expenditure hardly changed, edging down from $2.81 \%$ to $2.74 \%$ of GDP. The right-wing government in the $1982-1998$ period decreased military expenditure to $1.18 \%$ of GDP in 1998. In 2005, when the left-wing government of SPD and Greens was replaced by another grand coalition of CDU/CSU and SPD, military expenditure amounted to $1.03 \%$ of GDP.

Columns (1) to (3) in Table 2 show the means of military expenditure (in percent of GDP) in levels and growth rates under left-wing, center, and right-wing governments. Military expenditure accounted for 2.21\% under left-wing, 2.14\% under center, and 3.01\% of GDP under right-wing governments. Variance analysis shows that the differences of the means in levels are statistically significant at the $10 \%$ level. Individual tests show that the differences between the means between left-wing and right-wing governments are statistically significant at the $10 \%$ level. The growth rate in military expenditure (in percent of GDP) was about $-1.56 \%$ under left-wing, $-1.16 \%$ under center, and $-2.30 \%$ under right-wing governments. Differences do not turn out to be statistically significant.

Bjørnskov’s (2008a) index refers to the Henisz (2000) database on political outcomes since the $19^{\text {th }}$ century, and the general approach to measuring political ideology follows along the lines of Bjørnskov (2005, 2008b). However, as compared to the index employed in Bjørnskov (2005, 2008b), the Bjørnskov (2008a) index, 'takes the social democratic party in a 
given country as an internationally comparable anchor around which other parties are placed on a five-point scale $(-1 ;-.5 ; 0 ; .5 ; 1)$ from left to right' (Bjørnskov 2008a, 5). The ideology scores of each government party are weighted with their relative share of all government party seats in parliament in order to consider differing degrees of influence on government policy. This procedure addresses the ideological position of the government and the parliament. The Bjørnskov (2008a) index stresses the potential importance of the domestic political environment, and particularly whether governments have a majority in parliament or not. Figure 3 shows that the Bjørnskov (2008a) index is hardly correlated with the growth rate in military expenditure: the correlation coefficient is -0.04 .

The CMP data are based on content analysis of party platforms. The CMP data include ideological scores of the German parties in the national parliament since 1949. As the scores are based on manifestos prepared for national elections, they vary by legislative periods and not by years. The basic CMP score measures parties’ positions on a left-right (L-R) dimension assuming values between -31 (strongly left-wing) and 50 (strongly right-wing) for German parties over the period 1949-2011. To measure government ideology based on the CMP data, we use the L-R scores of the individual parties in government (weighted with each government party's relative share of all government party seats in parliament). The weighted government ideology measure based on the L-R dimension assumes values between -18.44 (strongly left-wing) and 50 (strongly right-wing) in our sample. Figure 4 shows that the weighted government ideology measure based on the L-R dimension is somewhat positively correlated with the growth rate in military expenditure, indicating that growth in military expenditure was somewhat higher under right-wing governments (the correlation coefficient is 0.18 ).

Whitten and Williams $(2011,118)$ describe: 'In the extant literature on the influence of government ideology on military spending, government ideological positions have been collapsed onto a single left-right scale, based on the assumption that hawkish foreign policies should occur among more right-wing governments. We propose replacing this with a two- 
dimensional conceptualization of government ideology that allows for a full range of combinations of government ideology in terms of welfare and international policies.' Following Whitten and Williams (2011), we use the two CMP sub-indices on party positions: support for international peace and support for welfare (both weighted with each government party's relative share of all government party seats in parliament). Figures 5 and 6 show that government ideology measured by support for international peace and support for welfare was hardly correlated with growth in military expenditure (the correlation coefficients are 0.10 and -0.06 ).

Table 3 shows the correlation coefficients between the individual government ideology indices. The baseline government ideology variable Left is strongly correlated with Bjørnskov’s (2008a) ideology variable ( $r=-0.93$ ), quite correlated with the CMP Left-Right scale and the CMP Welfare variable ( $r=-0.49$ and 0.58 ), and hardly correlated with the CMP International Peace measure $(r=-0.10)$.

\section{Empirical Model}

The baseline regression model has the following form:

$$
\begin{gathered}
\Delta \text { In Military expenditure }(\% \text { of GDP })_{t}=\beta_{k} \text { Ideology }_{k t}+\Sigma_{l} \gamma_{k l} \Delta \ln X_{l t} \\
+\varepsilon_{k} \text { German reunification dummy } \text { dum }_{t}+\lambda_{k}+u_{k t} \\
\text { with } \mathrm{k}=1, \ldots, 5 ; \mathrm{l}=1, \ldots, 3 ; \mathrm{t}=1951, \ldots, 2011
\end{gathered}
$$

where the dependent variable $\Delta \ln$ Military expenditure $(\% \text { of GDP })_{t}$ is the growth rate in military expenditure (in percent of GDP) in period t. Ideology $y_{k t}$ describes the ideological orientation of the respective government (we use five different ideology measures). $\Sigma_{l} \Delta \ln X_{l t}$ contains three control variables. We follow the related literature by including the growth rate in the population ( $\Delta \ln$ Population $_{t}$ ), the growth rate in GDP per capita ( $\Delta \ln$ GDP per capita $)$, and the growth rate in overall government spending (as percent of GDP; $\Delta \ln$ Government 
spending $\left.(\% \text { of } G D P)_{t}\right)$. We include government spending excluding spending for social affairs, because there is no time series for government spending including spending for social affairs starting in the 1950s. German reunification dummy is a dummy variable that takes on the value 1 in the year 1991 and the value 0 otherwise. This coding implies that a shift in levels occurred in $1991 .{ }^{4}$ We therefore address institutional changes after the fall of the Iron Curtain. $\lambda_{k}$ is a constant and $u_{k t}$ is an error term. Germany did not have military rivals after the end of the Second World War, and political institutions did not change. Due to the blame that it was given for the Second World War, Germany was also not likely to be involved in any military conflicts and certainly would not dispatch troops (although Germany joined the NATO in 1955). We therefore do not include other explanatory variables such as military expenditure by rivals, political institutions or a measure for the likelihood of involvement in a military conflict that have been proposed by many empirical studies on military expenditure. ${ }^{5}$

We estimate an ordinary least squares (OLS) model with standard errors robust to heteroskedasticity (Huber/White/sandwich standard errors - see Huber 1967 and White 1980). The Durbin-Watson test for serial correlation in the errors does not imply the existence of serial correlation. In any event, using the generalized least squares method to estimate the parameters in a linear regression model in which the error terms are serially correlated does not change the inferences (Prais-Winsten estimator with robust standard errors).

\section{Results}

Table 4 shows the regression results. The variable Left and the individual coalition type dummy variables do not turn out to be statistically significant. The growth rate in government

\footnotetext{
${ }^{4}$ Alternatively, we included a dummy variable that takes on the value 1 in the 1991-2011 period and the value 0 in the 1951-1990 period. The alternative coding implies that a shift in the growth rate after 1990 occurred. Inferences regarding government ideology do not change.

${ }^{5}$ See, for example, Albalate et al. (2012), Bove and Brauner (forthcoming), Bove and Nisticò (2014), Brauner (forthcoming), Collier and Hoeffler (2007), Dunne et al. (2008), Gadea and Montanes (2001), Nordhaus et al. (2012), Sandler and Hartley (2007), and Solomon (2005).
} 
spending (in percent of GDP) is statistically significant at the $1 \%$ level in columns (2) and (4). The numerical meaning of the effect is that when government spending (in percent of GDP) increased by $1 \%$, military expenditure (in percent of GDP) increased by about $1.21 \%$. The elasticity is likely to be larger than one because our measure of government expenditure does not include spending for social affairs. The coefficients of the growth rates in population and GDP per capita and the reunification dummy lack statistical significance.

Previous studies on ideology-induced policy making in Germany showed that government ideology influenced economic policy making in the 1970s and 1980s: left-wing governments spent more than right-wing governments. Thanks to the decline in electoral cohesion after the fall of the Iron Curtain, it is also conceivable that ideology-induced policy making changed after 1990. We therefore include dummy variables for the 1970-1990 period and the 1991-2011 period and interact the individual dummy variables with the variable Left. The results in Table 5 show, however, that government ideology had no statistically significant effect in the $1970-1990$ period and the $1991-2011$ period.

Table 6 shows that government ideology as measured by Bjørnskov (2008a) does not turn out to be statistically significant. Previous studies already arrived at the conclusion that using the measure for government ideology of Bjørnskov (2008a) - and using the measure of Potrafke (2009b) that resembles the coding of the variable Left - does not change the inferences regarding ideology-induced policy-making in OECD countries (e.g., Potrafke 2010). ${ }^{6}$ More generally, Pickering and Rockey (2011) concluded that alternative ways of measuring government ideology do not change the inferences regarding ideology-induced policy-making in OECD countries, even when a government ideology measure based on manifesto data is included.

\footnotetext{
${ }^{6}$ Other recent empirical studies on partisan politics include Hartmann (2014), Herwartz and Theilen (2014), Brech and Potrafke (2014), and Wiese (2014).
} 
Table 7 shows the results when government ideology is measured by the CMP L-R scale. The government ideology variable attains statistical significance at the $1 \%$ level in columns (2), (4), and (6), indicating that right-wing governments increased the growth in military expenditure. The growth in military expenditure increased by about 2.4 percentage points, when the ideology variable (right-wing) increased by one standard deviation. This result contrasts with the results shown in Tables 4 to 6 . The effect in Table 7 , however, is sensitive to the observations until the early 1960s. The government ideology variable based on the CMP L-R scores assumes values between -18 (extreme left-wing) and 50 (extreme right-wing) over the period 1951-2011. Over the periods 1951-1957 and 1963-1969 the government ideology variable assumes negative values indicating that these conservative governments were actually quite left-wing. By contrast, over the period 1958-1961 the government ideology variable based on the CMP L-R scores assumes values between 46 and 50. This drastic change in the government ideology variable in the late 1950s reveals the shortcomings of the CMP data when the quality of party manifestos is low (see also Gemenis 2013). ${ }^{7}$ The party program that was used to code the ideology of the Christian Democratic Union (CDU) relating to the elections in 1957 was significantly shorter than all other CDU party platforms: the party program only included 18 sentences compared to 393 sentences on average over our sample period. The effect shown in Table 7 thus cannot be generalized.

Table 8 shows the results when government ideology is measured by support for international peace and support for welfare (CMP data). We follow Whitten and Williams (2011) and include both government ideology variables in one specification. The results do not show that government ideology as measured by both variables had a significant effect over the periods 1951-2011 and 1970-1990 (the coefficient estimate of the welfare variable is statistically significant at the $10 \%$ level in column 2 notwithstanding). By contrast, the

\footnotetext{
${ }^{7}$ Criticism of the CMP also encompasses electoral motives: politicians may well design manifestos to become (re-)elected. It is conceivable that manifestos thus do not describe pure ideology.
} 
interaction term between the international peace variable and the dummy variable for the 1991-2011 period is statistically significant at the 1\% level in columns (5) and (6). This effect indicates that growth in military expenditure was lower under governments that supported international peace over the 1991-2011 period.

Military spending often involves long-run contracts with arms manufacturers. To deal with lagged effects of government ideology on changes in military spending, we included government ideology in period $t-1, t-2, t-3, t-4$, and $t-5$. When we use the variable $L e f t$ and the index of Bjørnskov (2008a), government ideology in period $t-1, t-3, t-4$, and $t-5$ lacks statistical significance. Government ideology in period $t-2$ attains statistical significance and indicates that left-wing governments had higher military expenditure (results not shown). The CMP L-R scale variable in period $t-1$ and $t-2$ is positive and statistically significant, indicating that right-wing governments increased growth in military expenditure. By contrast, the CMP L-R scale variable in period $t-5$ is negative and statistically significant, indicating that rightwing governments decreased growth in military expenditure. The CMP International Peace variable is negative and statistically significant in period $t-5$. The CMP Welfare variable does not turn out to be statistically significant in periods $t-1$ to $t-5$.

Due to the Second World War, ideology-induced policies were less pronounced in the 1950s and early 1960s - a period in which right-wing governments held office. Citizens were more concerned with reconstructing the country than with ideology-induced policies. We therefore also estimated the models for the 1966-2011 period. Inferences do not change when we use the variable Left, the individual coalition type dummy variables, and the Bjørnskov (2008a) index. When we use the CMP L-R score variable, the results show that left-wing governments posted lower growth in military expenditure over the period 1991-2011. When we use the international peace and welfare variables, the results corroborate the findings shown in Table 8. 


\section{Conclusion}

Why was government ideology not correlated with military expenditure in Germany over the 1951-2011 period? Three explanations spring to mind: firstly, the major parties CDU/CSU, SPD, and FDP agreed on how to evaluate international risks and threats. The CDU/CSU, SPD, and FDP shared foreign policy strategies by tying Germany to the NATO and the European Union. To be sure, the NATO expects military expenditure to amount to $2 \%$ of the member states' GDP. ${ }^{8}$ German military expenditure has not matched the $2 \%$-of-GDP threshold for many decades. However, no political party endorsed increasing military expenditure. Secondly, party alignment notwithstanding, politicians were election-motivated and believed that military expenditure would not win votes. By contrast, left-wing and rightwing governments increased social expenditure, and considered it as more likely to get them (re-)elected (e.g., Potrafke 2012; Kauder et al. 2014). Government ideology retired to the background at the federal level. ${ }^{9}$ Thirdly, an important reason for why the left-wing governments in the 1970s advocated military spending (see also Eichenberg and Stoll 2003) is that the then-chancellor Helmut Schmidt and the minister of defence Georg Leber were both former soldiers who fought in the Second World War.

A key issue is whether government ideology will influence German military expenditure in the near future. Thanks to new international risks and threats - Islamist terror and the conflicts in the East Ukraine are cases in point - German military spending may increase. ${ }^{10}$ Deficiencies in the German army that were covered by the media in autumn 2014 and the German government's announcement that it seeks to turn the army into an attractive workplace may also give rise to higher military spending. In fact, the government that is likely

\footnotetext{
${ }^{8}$ See Bove and Cavatorta (2012) on the composition of military expenditure in NATO countries (personnel, equipment, infrastructure, other).

${ }^{9}$ In the German states, government ideology did have an effect: right-wing governments spent more on universities, introduced tuition fees, hired more cops, and promoted economic freedom (Oberndorfer and Steiner 2007; Kauder and Potrafke 2013; Tepe and Vanhuysse 2013; Potrafke 2013).

${ }^{10}$ Smith (2013) predicts that the military industry is likely to become more concentrated when the world gets more peaceful and military expenditure decreases.
} 
to increase military expenditure consists of the conservative CDU/CSU and the socialdemocratic SPD. The consensus between left-wing and right-wing parties in military affairs and in increasing the size of the government appears to persist.

\section{Acknowledgments}

We would like to thank Vincenzo Bove, Georgios Efthyvoulou, Andreas Glas, Todd Sandler, Vassilis Sarantidis, Jürgen Schnell, Ron Smith, and an anonymous referee for their helpful comments. We are also grateful to Lisa Giani-Contini for proof-reading the paper. Alexander H. Schwemmer and Leonard Thielmann provided excellent research assistance. 


\section{References}

Albalate, D., G. Bel, and F. Elias. 2012. "Institutional Determinants of Military Spending.” Journal of Comparative Economics 40, 279-290.

Alesina, A. 1987. “Macroeconomic Policy in a Two-Party System as a Repeated Game.” Quarterly Journal of Economics 102, 651-678.

Auerswald, D. P., and S. M. Saideman. 2014. NATO in Afghanistan - Fighting Together, Fighting Alone. Princeton, NJ: Princeton University Press.

Bayer, S., and L. Naunheim. 2014. "Verteidigungshaushalt und Neuausrichtung der Bundeswehr - Anpassungsperspektiven und ungelöste Herausforderungen.” In Streitkräftemanagement, edited by E.-M. Kern and G. Richter, 191-209. Wiesbaden: Springer.

Bjørnskov, C. 2005. “Does Political Ideology Affect Economic Growth?” Public Choice 123, 133-146.

Bjørnskov, C. 2008a. "Political Ideology and the Structure of National Accounts in the Nordic Countries, 1950-2004.” Paper presented at the annual meeting of the European Public Choice Society, Jena, March 27-30.

Bjørnskov, C. 2008b. “The Growth-Inequality Association: Government Ideology Matters.” Journal of Development Economics 87, 300-308.

Bove, V., and J. Brauner. Forthcoming. "The Demand for Military Expenditure in Authoritarian Regimes.” Defence and Peace Economics.

Bove, V., and E. Cavatorta. 2012. "From Conscription to Volunteers: Budget Shares in NATO Defence Spending.” Defence and Peace Economics 23, 273-288.

Bove, V., G. Efthyvoulou, and A. Navas. 2014. "Political Cycles in Public Expenditure: Butter vs Guns.” Sheffield Economic Research Paper 2013016.

Bove, V., and R. Nisticò. 2014. "Military in Politics and Budgetary Allocations.” Journal of Comparative Economics 42, 1065-1078.

Brauner, J. Forthcoming. "Military Spending and Democracy.” Defence and Peace Economics.

Brech, V., and N. Potrafke. 2014. “Donor Ideology and Types of Foreign Aid.” Journal of Comparative Economics 42, 61-75.

Budge, I., H. Keman, and J. Woldendorp. 1993. “Political Data 1945-1990. Party Government in 20 Democracies.” European Journal of Political Research 24, 1-119.

Budge, I., H.-D. Klingemann, A. Volkens, J. Bara, E. Tanenbaum, R. C. Fording, D. J. Hearl, H. M. Kim, M. McDonald, and S. Mendez. 2001. Mapping Policy Preferences. 
Estimates for Parties, Electors, and Governments 1945-1998. Oxford: Oxford University Press.

Collier, P., and A. Hoeffler. 2007. "Unintended Consequences: Does Aid Promote Arms Races?” Oxford Bulletin of Economics and Statistics 69, 1-28.

Correa H., and J.-W. Kim. 1992. “A Causal Analysis of Defence Expenditures of the USA and the USSR.” Journal of Peace Research 29, 161-174.

Dalen, H. P., and O. H. Swank. 1996. “Government Spending Cycles: Ideological or Opportunistic?” Public Choice 89, 183-200.

Dunne, J. P., S. Perlo-Freeman, and R. P. Smith. 2008. “The Demand for Military Expenditure in Developing Countries: Hostility versus Capability.” Defence and Peace Economics 19, 293-302.

Eichenberg, R. C., and R. Stoll. 2003. "Representing Defense: Democratic Control of the Defense Budget in the United States and Western Europe.” Journal of Conflict Resolution 47, 399-422.

Gadea, M. D., and A. Montanes. 2001. “An Analysis of Defence Spending in Spain: A LongRun Approach.” Defence and Peace Economics 12, 369-393.

Gemenis, K. 2013. "What to Do (and not to Do) with the Comparative Manifestos Project Data.” Political Studies 61, 3-23.

Giegerich, B. 2003. "Mugged by Reality? German Defense in Light of the 2003 Policy Guidelines.” DIAS-Kommentare 10, Düsseldorf.

Griffin, L. J., M. Wallace, and J. Devine. 1982. “The Political Economy of Military Spending: Evidence from the United States.” Cambridge Journal of Economics 6, 1-14.

Hartmann, S. 2014. Partisan Policy-Making in Western Europe - How Ideology Influences the Content of Government Policies. Wiesbaden: Springer VS.

Henisz, W. 2000. "The Institutional Environment for Growth.” Economics and Politics 12, 1-31.

Herwartz, H., and B. Theilen. 2014. "Partisan Influence on Social Spending under Market Integration, Fiscal Pressure and Institutional Change.” European Journal of Political Economy 34, 409-424.

Hibbs, D. A. Jr. 1977. "Political Parties and Macroeconomic Policy.” American Political Science Review 71, 1467-1487.

Huber, P. J. 1967. “The Behavior of Maximum Likelihood Estimates under Nonstandard Conditions.” Proceedings of the Fifth Berkeley Symposium on Mathematical Statistics and Probability, 221-233. 
Karagol, E. T., and A. Turhan. 2008. "External Debt, Defence Expenditure and Political Business Cycles in Turkey.” Defence and Peace Economics 19, 217-224.

Kauder, B., B. Larin, and N. Potrafke. 2014. "Was bringt uns die große Koalition? Perspektiven der Wirtschaftspolitik.” Perspektiven der Wirtschaftspolitik 15, 88-101.

Kauder, B., and N. Potrafke. 2013. “Government Ideology and Tuition Fee Policy: Evidence from the German States.” CESifo Economic Studies 59, 628-649.

Klingemann, H.-D., A. Volkens, J. Bara, I. Budge, and M. McDonald. 2006. Mapping Policy Preferences II. Estimates for Parties, Electors, and Governments in Eastern Europe, the European Union and OECD 1990-2003. Oxford: Oxford University Press.

Kollias, C., and S. M. Paleologou. 2003. "Domestic Political and External Security Determinants of the Demand for Greek Military Expenditure.” Defence and Peace Economics 14, 437-445.

Maneval, H. 1994. “Defence Spending in West Germany.” Defence and Peace Economics 5, 221-246.

Nikolaidou, E. 2008. “The Demand for Military Expenditure: Evidence from the EU15 (1961-2005).” Defence and Peace Economics 19, 273-292.

Nincic, M., and T. R. Cusack. 1979. “The Political Economy of US Military Spending.” Journal of Peace Research 16, 101-115.

Nordhaus, W., J. R. Oneal, and B. R. Russett. 2012. “The Effects of the International Security Environment on National Military Expenditures: A Multi-Country Study.” International Organization 66, 491-515.

Oberndorfer, U., and V. Steiner. 2007. “Generationen- oder Parteienkonflikt? Eine empirische Analyse der deutschen Hochschulausgaben.” Perspektiven der Wirtschaftspolitik 8, 165-183.

Olson, M., and R. Zeckhauser. 1966. “An Economic Theory of Alliances.” Review of Economics and Statistics 48, 266-279.

Pickering, A. C., and J. Rockey. 2011. “Ideology and the Growth of Government.” Review of Economics and Statistics 93, 907-919.

Potrafke, N. 2009a. Konvergenz in der deutschen Finanz- und Sozialpolitik? Hamburg/Münster: LIT.

Potrafke, N. 2009b. “Did Globalization Restrict Partisan Politics? An Empirical Evaluation of Social Expenditures in a Panel of OECD Countries.” Public Choice 140, 105-124.

Potrafke, N. 2010. “Does Government Ideology Influence Deregulation of Product Markets? Empirical Evidence from OECD Countries.” Public Choice 143, 135-155. 
Potrafke, N. 2011. “Does Government Ideology Influence Budget Composition? Empirical Evidence from OECD Countries.” Economics of Governance 12, 101-134.

Potrafke, N. 2012. “Is German Domestic Social Policy Politically Controversial?” Public Choice 153, 393-418.

Potrafke, N. 2013. “Economic Freedom and Government Ideology across the German States.” Regional Studies 47, 433-449.

Sandler, T., and K. Hartley, eds. 2007. Handbook of Defence Economics Vol. 2. Amsterdam: North-Holland.

Sandler, T., and J. F. Forbes. 1980. "Burden Sharing, Strategy, and the Design of the NATO.” Economic Inquiry 18, 425-444.

Sandler, T., and H. Shimizu. 2014. "NATO Burden Sharing 1999-2010: An Altered Alliance.” Foreign Policy Analysis 10, 43-60.

Scheffé, H. 1953. “A Method for Judging all Contrasts in the Analysis of Variance.” Biometrika 40, 87-110.

Smith, R. 2013. "The Defense Industry in an Age of Austerity.” Economics of Peace and Security Journal 8, 18-22.

Solomon, B. 2004. “NATO Burden Sharing Revisited.” Defence and Peace Economics 15, 251-258.

Solomon, B. 2005. “The Demand for Canadian Defence Expenditures.” Defence and Peace Economics 16, 171-189.

Strauss, A. 2015. “Government ideology and arms exports.” Paper presented at the annual meeting of the European Public Choice Society, Groningen, April 7-10.

Tepe, M., and P. Vanhuysse. 2013. “Cops for Hire? The Political Economy of Police Employment in the German States.” Journal of Public Policy 33, 165-199.

Tridimas, G. 2015. "War, Disenfranchisement and the Fall of the Ancient Athenian Democracy.” European Journal of Political Economy 38, 102-117.

Volkens, A., P. Lehmann, N. Merz, S. Regel, A. Werner, and H. Schultze. 2014. The Manifesto Data Collection. Manifesto Project (MRG/CMP/MARPOR). Version 2014b. Berlin: Wissenschaftszentrum Berlin für Sozialforschung (WZB).

White, H. 1980. “A Heteroskedasticity-Consistent Covariance Matrix Estimator and a Direct Test for Heteroskedasticity.” Econometrica 48, 817-838.

Whitten, G. D., and L. K. Williams. 2011. "Buttery Guns and Welfare Hawks: The Politics of Defense Spending in Advanced Industrial Democracies.” American Journal of Political Science 55, 117-134. 
Wiese, R. 2014. “What Triggers Reforms in OECD Countries? Improved Reform Measurement and Evidence from the Healthcare Sector.” European Journal of Political Economy 34, 332-352.

Wlezien, C. 1996. “Dynamics of Representation: The Case of US Spending on Defense.” British Journal of Political Science 26, 81-103.

Woldendorp, J., H. Keman, and I. Budge. 1998. "Party Government in 20 Democracies: An Update 1990-1995.” European Journal of Political Research 33, 125-164.

Woldendorp, J., H. Keman, and I. Budge. 2000. Party Government in 48 Democracies 19451998: Composition, Duration, Personnel. Dordrecht: Kluwer Academic Publishers. 
Figure 1: Military expenditure (in percent of GDP), 1950-2011

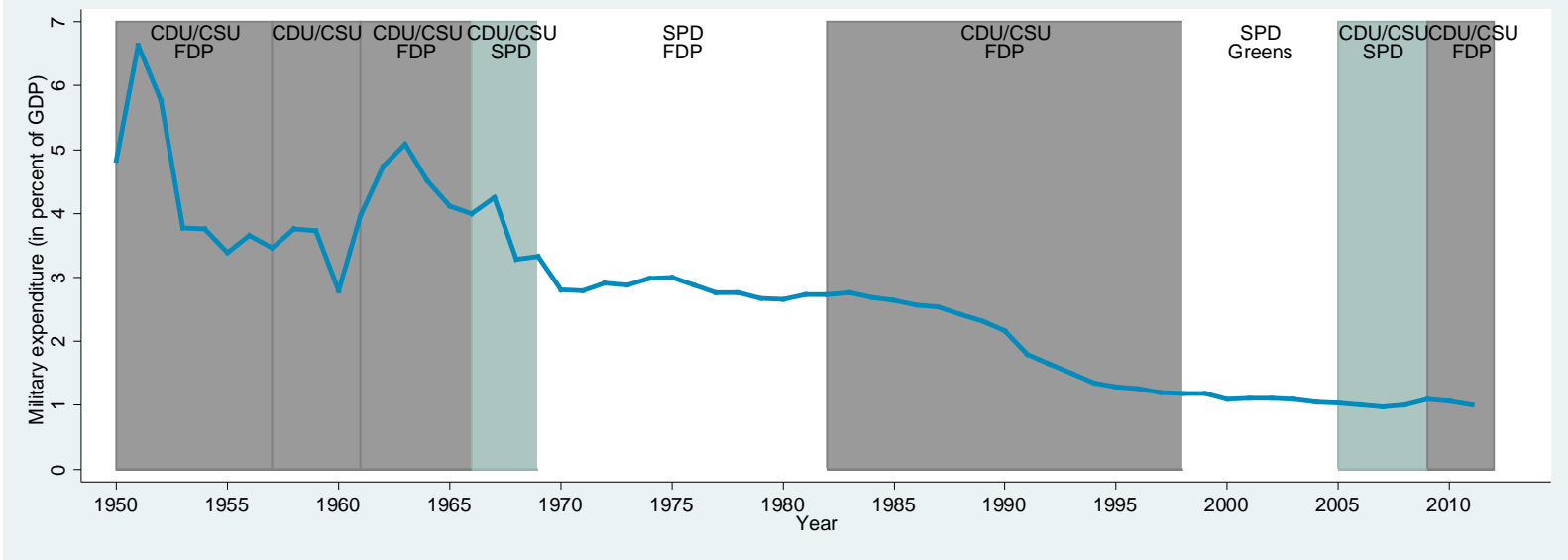

Source: Federal Statistical Office, own illustration.

Figure 2: Growth rate in military expenditure (in percent of GDP), 1951-2011

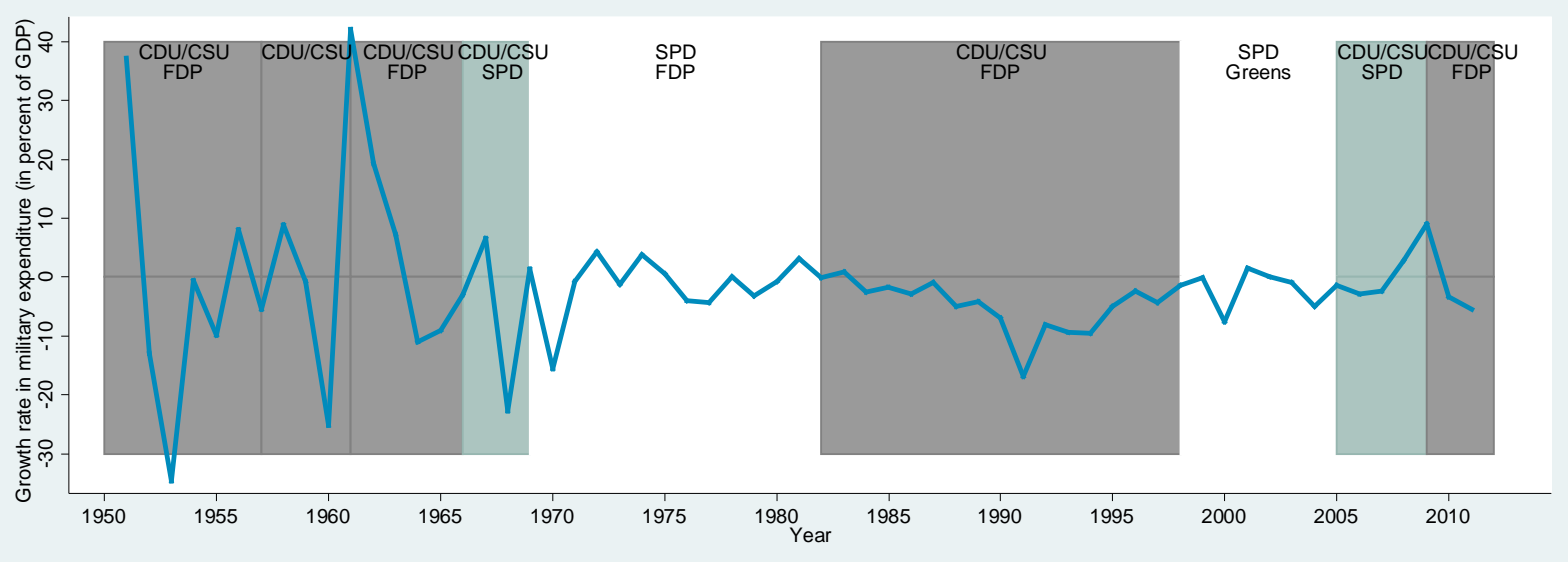

Source: Federal Statistical Office, own illustration. 
Figure 3: Correlation between the growth rate in military expenditure (in percent of GDP) and government ideology as measured by Bjørnskov (2008a), 1951-2011.

Correlation coefficient: -0.04

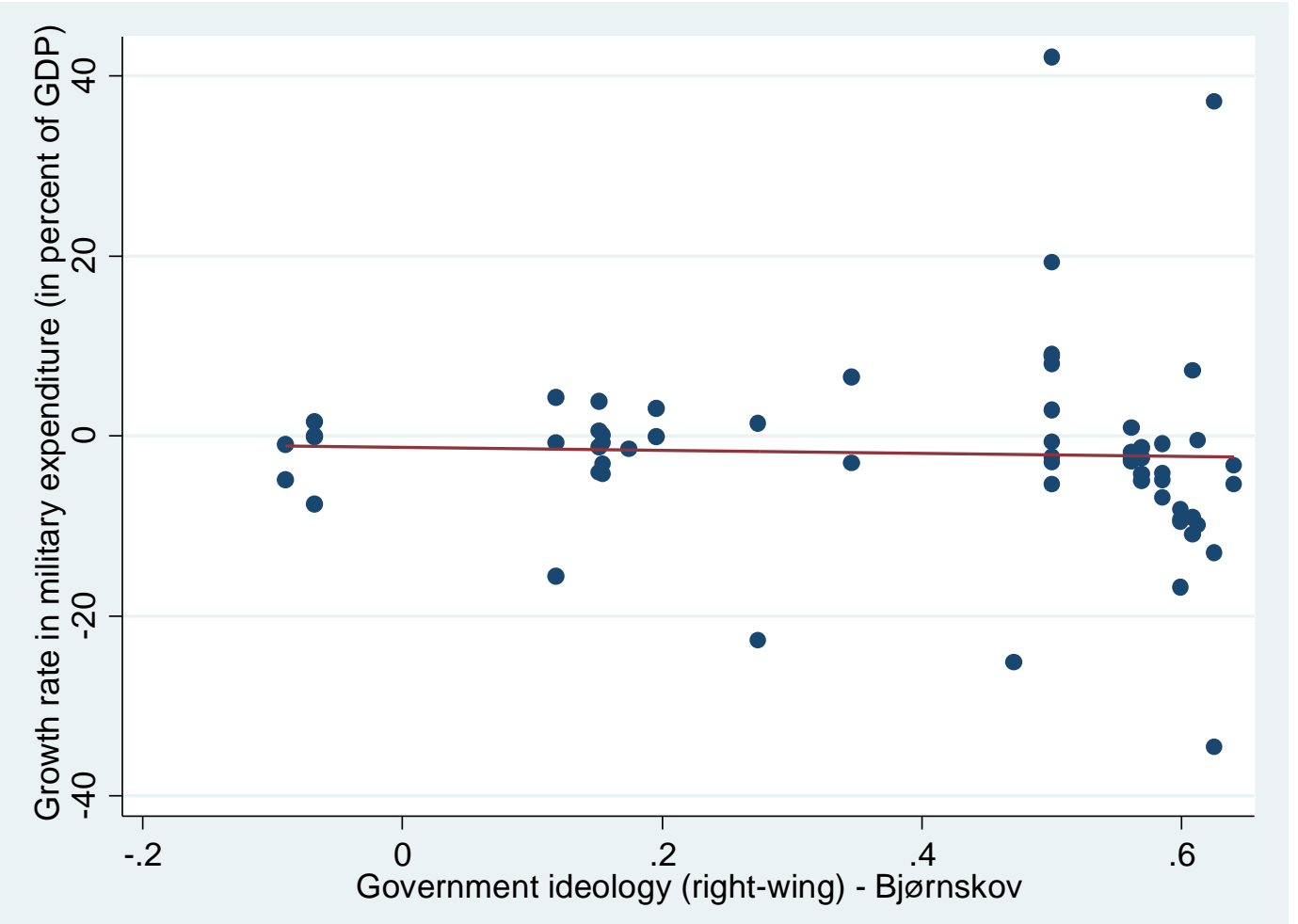

Source: Federal Statistical Office, Bjørnskov (2008a), and own calculations. 
Figure 4: Correlation between the growth rate in military expenditure (in percent of GDP) and government ideology as measured by the CMP Left-Right scale, 1951-2011.

Correlation coefficient: 0.18

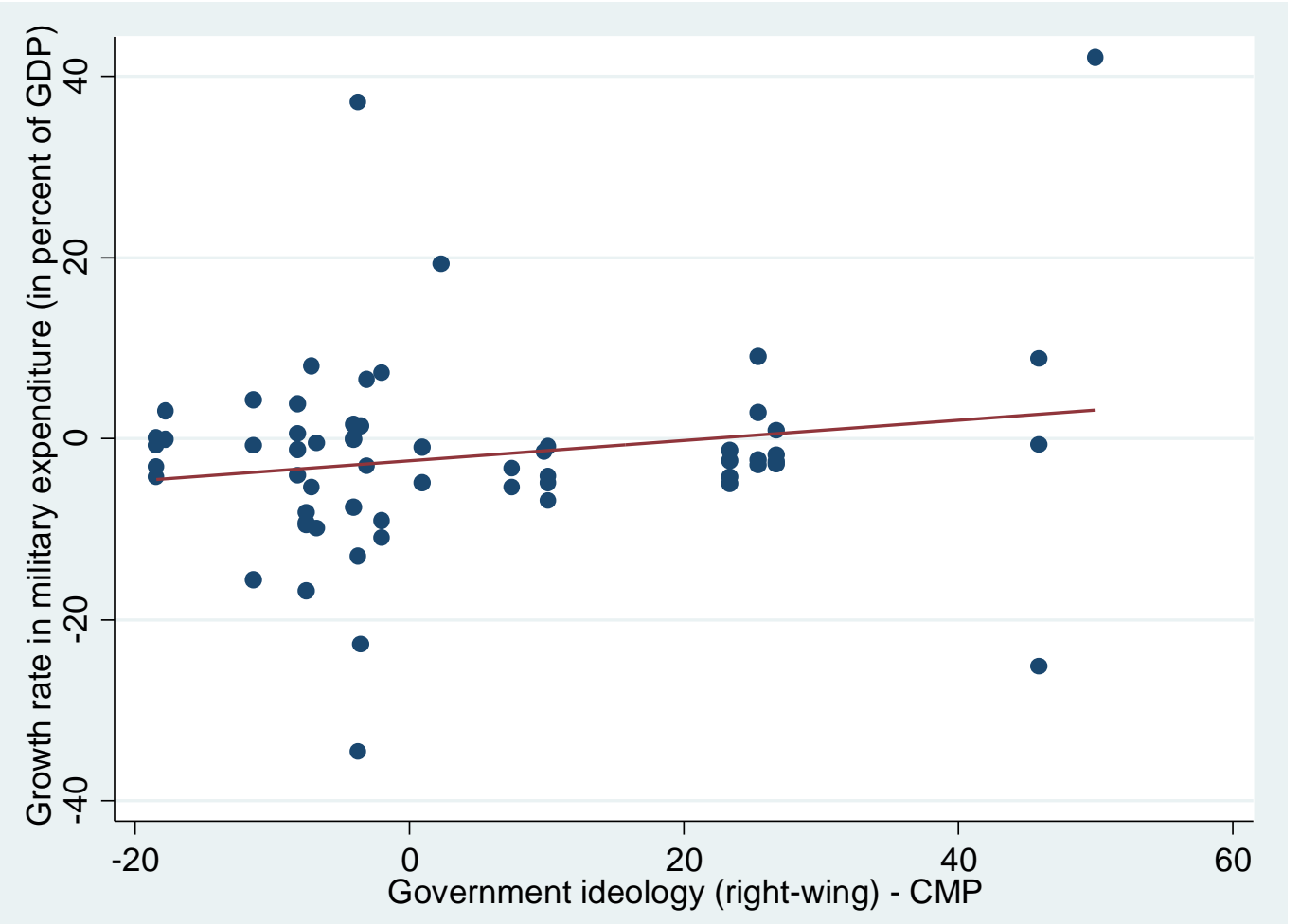

Source: Federal Statistical Office, Budge et al. (2001), Klingemann et al. (2006), Volkens et al. (2014), and own calculations. 
Figure 5: Correlation between the growth rate in military expenditure (in percent of GDP) and government ideology as measured by Support for International Peace (CMP data), 1951-2011. Correlation coefficient: 0.10

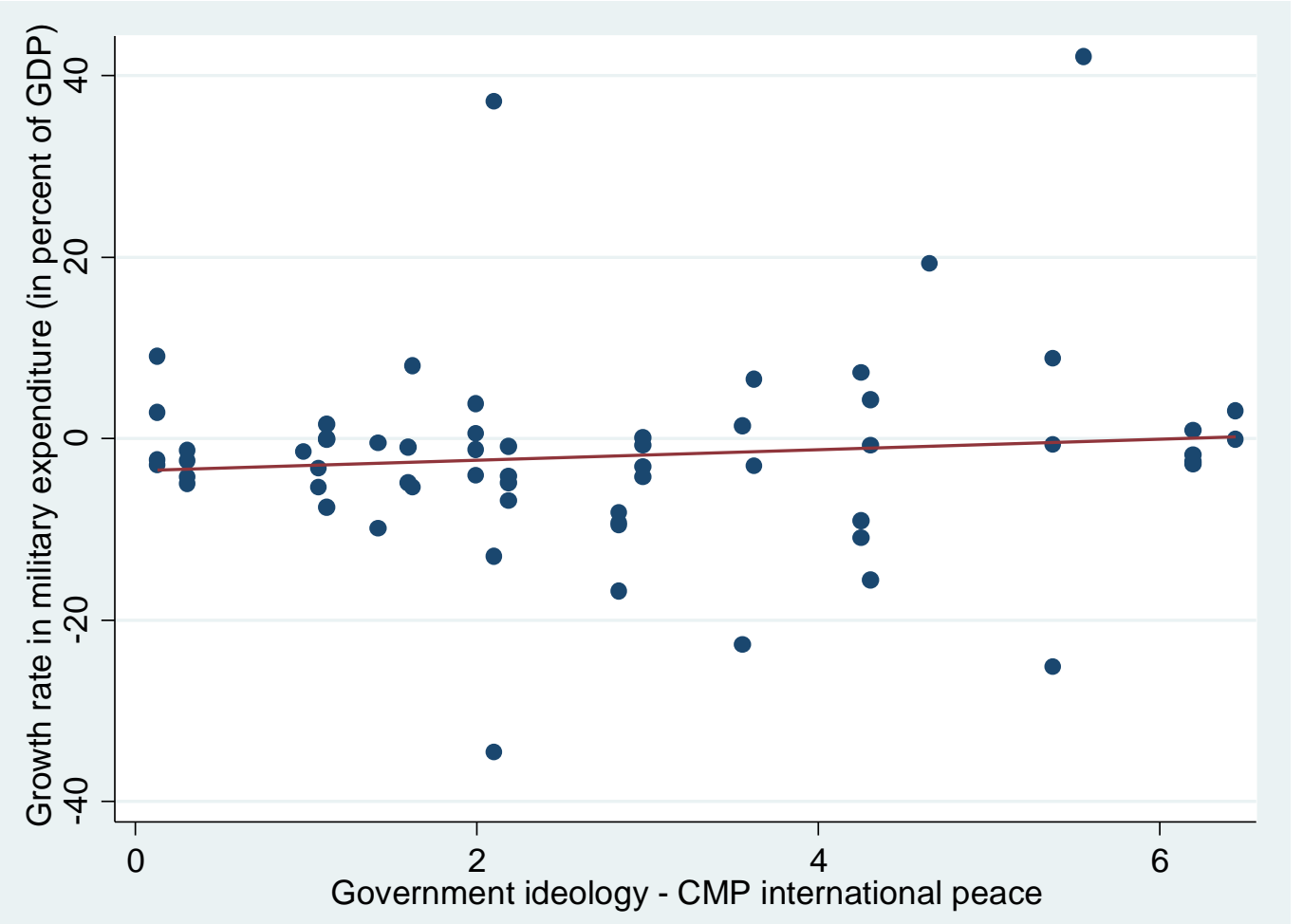

Source: Federal Statistical Office, Budge et al. (2001), Klingemann et al. (2006), Volkens et al. (2014), and own calculations. 
Figure 6: Correlation between the growth rate in military expenditure (in percent of GDP) and government ideology as measured by Support for Welfare (CMP data), 1951-2011.

Correlation coefficient: -0.06

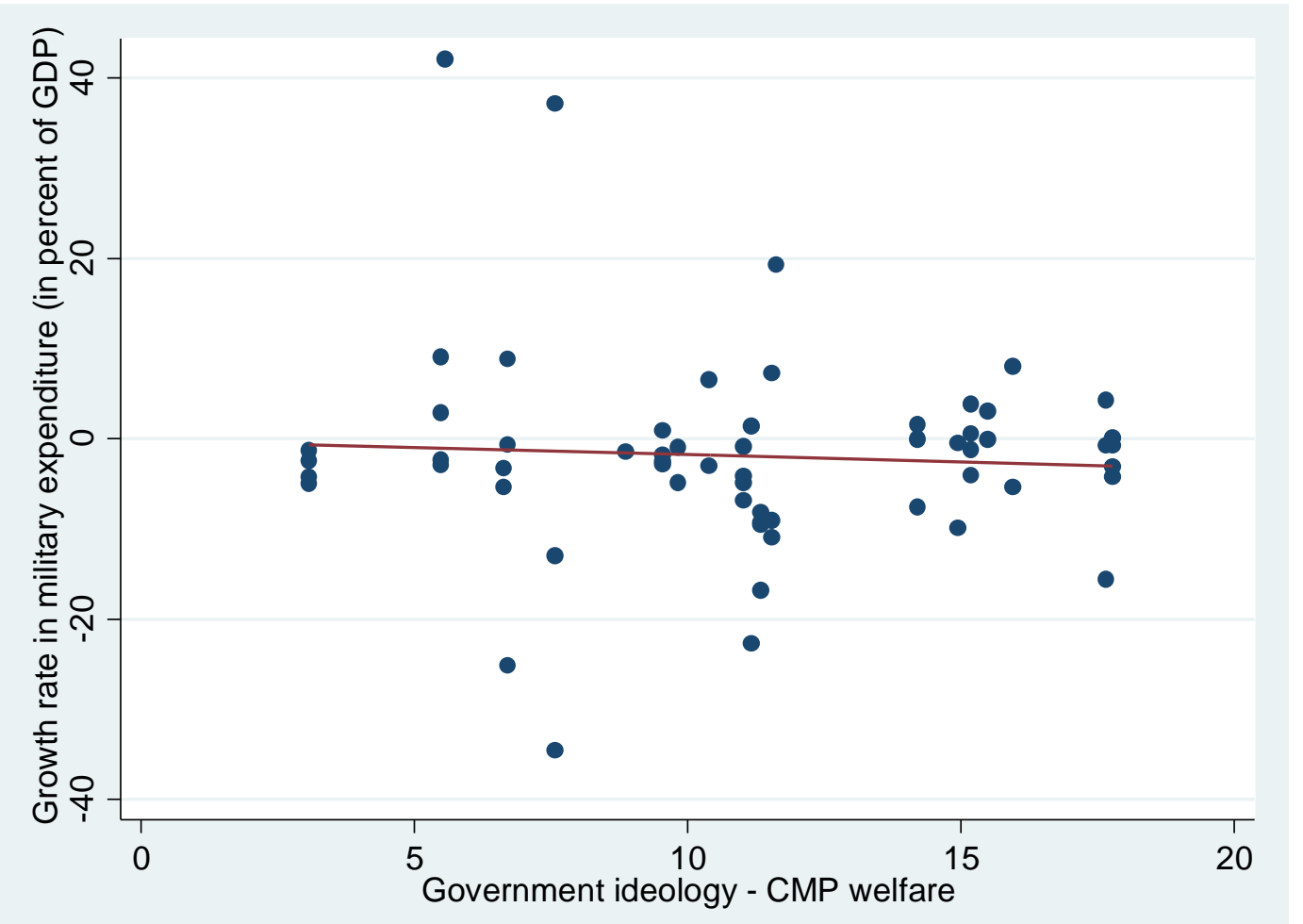

Source: Federal Statistical Office, Budge et al. (2001), Klingemann et al. (2006), Volkens et al. (2014), and own calculations. 
Table 1: Descriptive statistics and data sources

\begin{tabular}{lcccccl}
\hline Variable & Obs. & Mean & Std. Dev. & Min & Max & Source \\
\hline Military expenditure (\% of GDP) & 62 & 2.65 & 1.32 & 0.98 & 6.63 & Federal Statistical Office \\
Left-wing government & 62 & 0.38 & 0.46 & 0 & 1 & Own calculation \\
CDU/CSU/FDP & 62 & 0.56 & 0.50 & 0 & 1 & Own calculation \\
SPD/FDP & 62 & 0.21 & 0.41 & 0 & 1 & Own calculation \\
SPD/Greens & 62 & 0.11 & 0.32 & 0 & 1 & Own calculation \\
CDU/CSU/SPD & 62 & 0.11 & 0.32 & 0 & 1 & Own calculation \\
Ideology - Bjørnskov (right-wing) & 62 & 0.39 & 0.24 & -0.09 & 0.64 & Bjørnskov (2008a) \\
Ideology - CMP Left-Right scale & 62 & 4.42 & 17.69 & -18.44 & 50 & Budge et al. (2001), Klingemann et al. \\
$\quad$ right-wing) & & & & & & (2006), Volkens et al. (2014) \\
Ideology - CMP International Peace & 62 & 2.76 & 1.85 & 0.13 & 6.44 & Budge et al. (2001), Klingemann et al. \\
& & & & & & (2006), Volkens et al. (2014) \\
Ideology - CMP Welfare & 62 & 11.02 & 4.26 & 3.08 & 17.77 & Budge et al. (2001), Klingemann et al. \\
& & & & & & (2006), Volkens et al. (2014) \\
Population (in 1000) & 62 & 66632.73 & 11406.64 & 50958 & 82537 & Federal Statistical Office \\
GDP per capita (in 1000) & 62 & 14.08 & 10.28 & 0.98 & 33.60 & Federal Statistical Office \\
Government spending (\% of GDP) & 62 & 28.21 & 2.88 & 21.33 & 31.54 & Federal Statistical Office \\
Reunification dummy & 62 & 0.02 & 0.13 & 0 & 1 & Own calculation
\end{tabular}

Table 2: Military expenditure (in percent of GDP) and growth rate in military expenditure (in percent of GDP) under individual types of governments

\begin{tabular}{|c|c|c|c|c|c|c|c|}
\hline & \multicolumn{3}{|c|}{ Means } & \multirow{2}{*}{$\begin{array}{c}\text { Variance } \\
\text { analysis } \\
\text { F-Test } \\
(4)\end{array}$} & \multicolumn{3}{|c|}{ Individual tests } \\
\hline & $\begin{array}{l}\text { Left } \\
(1)\end{array}$ & $\begin{array}{l}\text { Center } \\
\text { (2) }\end{array}$ & $\begin{array}{c}\text { Right } \\
\text { (3) }\end{array}$ & & $\begin{array}{l}\text { Left - } \\
\text { Center } \\
\text { (5) }\end{array}$ & $\begin{array}{l}\text { Right - } \\
\text { Center } \\
\text { (6) }\end{array}$ & $\begin{array}{l}\text { Left - } \\
\text { Right } \\
\text { (7) }\end{array}$ \\
\hline $\begin{array}{l}\text { Military expenditure } \\
\text { (\% of GDP) 1950-2011 }\end{array}$ & 2.21 & 2.14 & 3.01 & $\begin{array}{l}3.11^{*} \\
(0.05)\end{array}$ & $\begin{array}{c}0.08 \\
(0.99)\end{array}$ & $\begin{array}{l}-0.87 \\
(0.27)\end{array}$ & $\begin{array}{l}-0.80^{*} \\
(0.09)\end{array}$ \\
\hline $\begin{array}{l}\text { Growth rate in } \\
\text { military expenditure } \\
\text { (\% of GDP) 1951-2011 }\end{array}$ & -1.56 & -1.16 & -2.30 & $\begin{array}{c}0.04 \\
(0.96)\end{array}$ & $\begin{array}{l}-0.40 \\
(1.00)\end{array}$ & $\begin{array}{l}1.14 \\
(0.97)\end{array}$ & $\begin{array}{c}0.74 \\
(0.97)\end{array}$ \\
\hline
\end{tabular}

Notes: * implies to reject the null hypothesis at the $10 \%$ significance level. Column (4) shows F-statistics and pvalues in brackets. Columns (5) to (7) show the individual differences of the means and p-values in brackets. The p-values in columns (5) to (7) refer to the test of Scheffé (1953). 
Table 3: Correlation matrix of ideology indices (1951-2011 period)

\begin{tabular}{|c|c|c|c|c|c|}
\hline & $\begin{array}{l}\text { Left-wing } \\
\text { government }\end{array}$ & $\begin{array}{l}\text { Ideology - } \\
\text { Bjørnskov } \\
\text { (right-wing) }\end{array}$ & $\begin{array}{l}\text { Ideology - } \\
\text { CMP Left- } \\
\text { Right scale } \\
\text { (right-wing) }\end{array}$ & $\begin{array}{c}\text { Ideology - } \\
\text { CMP } \\
\text { International } \\
\text { Peace }\end{array}$ & $\begin{array}{c}\text { Ideology - } \\
\text { CMP Welfare }\end{array}$ \\
\hline Left-wing government & 1.00 & & & & \\
\hline $\begin{array}{l}\text { Ideology - Bjørnskov } \\
\text { (right-wing) }\end{array}$ & -0.93 & 1.00 & & & \\
\hline $\begin{array}{l}\text { Ideology - CMP } \\
\text { Left-Right scale } \\
\text { (right-wing) }\end{array}$ & -0.49 & 0.43 & 1.00 & & \\
\hline $\begin{array}{l}\text { Ideology - CMP } \\
\text { International Peace }\end{array}$ & -0.10 & 0.05 & 0.09 & 1.00 & \\
\hline $\begin{array}{l}\text { Ideology - CMP } \\
\text { Welfare }\end{array}$ & 0.58 & -0.56 & -0.79 & 0.23 & 1.00 \\
\hline
\end{tabular}


Table 4: Regression results. OLS estimator with robust standard errors.

Dependent variable: growth rate in military expenditure (in percent of GDP) in the 1951-2011 period

\begin{tabular}{lcccc}
\hline & $(1)$ & $(2)$ & $(3)$ & $(4)$ \\
\hline Left & 0.787 & -0.627 & & \\
CDU/CSU/FDP & $(0.29)$ & $(0.36)$ & & -1.141 \\
& & & $(0.25)$ & $(0.07)$ \\
SPD/FDP & & -0.217 & -2.944 \\
& & & $(0.05)$ & $(0.82)$ \\
SPD/Greens & & -0.749 & 2.705 \\
& & & $(0.19)$ & $(0.93)$ \\
$\Delta \ln$ Population & & -2.064 & & -2.509 \\
& & $(1.13)$ & & $(1.27)$ \\
$\Delta \ln$ GDP per capita & 0.390 & & 0.574 \\
& & $(0.87)$ & & $(1.09)$ \\
Sln Government spending (\% of GDP) & & $1.196 * * *$ & & $1.231^{* * *}$ \\
& & $(7.30)$ & & $(7.47)$ \\
Reunification dummy & & 42.01 & & 55.33 \\
& & $(0.85)$ & & $(1.02)$ \\
Constant & -2.848 & -1.160 & -3.611 \\
& & $(1.26)$ & $(0.31)$ & $(1.24)$ \\
\hline Observations & & 61 & 61 & 61 \\
R-squared & 61 & 0.531 & 0.002 & 0.546 \\
\hline
\end{tabular}

Notes: Absolute values of t-statistics in brackets; ***: significant at the $1 \%$ level. 
Table 5: Regression results. OLS estimator with robust standard errors.

Leftist government.

Interaction with 1970-1990 decadal dummy and 1991-2011 decadal dummy.

Dependent variable: growth rate in military expenditure (in percent of GDP) in the 1951-2011 period

\begin{tabular}{|c|c|c|c|c|}
\hline & $(1)$ & $(2)$ & (3) & $(4)$ \\
\hline Left & $\begin{array}{l}0.449 \\
(0.11)\end{array}$ & $\begin{array}{l}3.388 \\
(0.94)\end{array}$ & $\begin{array}{l}-1.043 \\
(0.28)\end{array}$ & $\begin{array}{l}-1.603 \\
(0.61)\end{array}$ \\
\hline Dummy 1970-1990 & $\begin{array}{l}-0.853 \\
(0.27)\end{array}$ & $\begin{array}{l}1.013 \\
(0.41)\end{array}$ & & \\
\hline Left * Dummy 1970-1990 & $\begin{array}{l}1.061 \\
(0.25)\end{array}$ & $\begin{array}{l}-5.485 \\
(1.10)\end{array}$ & & \\
\hline Dummy 1991-2011 & & & $\begin{array}{l}-4.852 \\
(1.34)\end{array}$ & $\begin{array}{c}-0.0627 \\
(0.02)\end{array}$ \\
\hline Left * Dummy 1991-2011 & & & $\begin{array}{l}6.098 \\
(1.44)\end{array}$ & $\begin{array}{l}5.439 \\
(1.32)\end{array}$ \\
\hline$\Delta \ln$ Population & & $\begin{array}{c}-0.422 * * \\
(2.26)\end{array}$ & & $\begin{array}{c}-0.424^{* *} \\
(2.55)\end{array}$ \\
\hline$\Delta \ln$ GDP per capita & & $\begin{array}{l}0.462 \\
(0.96)\end{array}$ & & $\begin{array}{l}0.477 \\
(0.89)\end{array}$ \\
\hline$\Delta \ln$ Government spending ( $\%$ of GDP) & & $\begin{array}{c}1.207^{* * *} \\
(7.56)\end{array}$ & & $\begin{array}{c}1.206 * * * \\
(7.30)\end{array}$ \\
\hline Constant & $\begin{array}{l}-2.034 \\
(0.66) \\
\end{array}$ & $\begin{array}{l}-4.625 \\
(1.28) \\
\end{array}$ & $\begin{array}{r}-0.756 \\
(0.23) \\
\end{array}$ & $\begin{array}{r}-4.391 \\
(1.04) \\
\end{array}$ \\
\hline Observations & 61 & 61 & 61 & 61 \\
\hline R-squared & 0.002 & 0.535 & 0.025 & 0.539 \\
\hline
\end{tabular}

Notes: Absolute values of t-statistics in brackets; **/***: significant at the 5/1\% level. 
Table 6: Regression results. OLS estimator with robust standard errors.

Government ideology as measured by Bjørnskov (2008a).

Dependent variable: growth rate in military expenditure (in percent of GDP) in the 1951-2011 period

\begin{tabular}{|c|c|c|c|c|c|c|}
\hline & $(1)$ & $(2)$ & (3) & $(4)$ & $(5)$ & $(6)$ \\
\hline Ideology - Bjørnskov (right-wing) & $\begin{array}{l}-1.724 \\
(0.35)\end{array}$ & $\begin{array}{l}-1.276 \\
(0.36)\end{array}$ & $\begin{array}{l}-1.357 \\
(0.23)\end{array}$ & $\begin{array}{l}-6.682 \\
(1.32)\end{array}$ & $\begin{array}{l}1.168 \\
(0.12)\end{array}$ & $\begin{array}{l}1.689 \\
(0.22)\end{array}$ \\
\hline Dummy 1970-1990 & & & $\begin{array}{l}0.348 \\
(0.12)\end{array}$ & $\begin{array}{l}-5.870 \\
(1.52)\end{array}$ & & \\
\hline $\begin{array}{l}\text { Ideology - Bjørnskov (right-wing) * } \\
\text { Dummy 1970-1990 }\end{array}$ & & & $\begin{array}{l}-1.755 \\
(0.24)\end{array}$ & $\begin{array}{l}12.45 \\
(1.45)\end{array}$ & & \\
\hline Dummy 1991-2011 & & & & & $\begin{array}{c}-0.0539 \\
(0.02)\end{array}$ & $\begin{array}{l}4.715 \\
(1.00)\end{array}$ \\
\hline $\begin{array}{l}\text { Ideology - Bjørnskov (right-wing) * } \\
\text { Dummy 1991-2011 }\end{array}$ & & & & & $\begin{array}{l}-6.040 \\
(0.59)\end{array}$ & $\begin{array}{l}-6.861 \\
(0.77)\end{array}$ \\
\hline$\Delta \ln$ Population & & $\begin{array}{l}-1.757 \\
(0.98)\end{array}$ & & $\begin{array}{c}-0.419 * * \\
(2.54)\end{array}$ & & $\begin{array}{c}-0.435 * * * \\
\quad(2.85)\end{array}$ \\
\hline$\Delta \ln$ GDP per capita & & $\begin{array}{l}0.391 \\
(0.86)\end{array}$ & & $\begin{array}{l}0.466 \\
(1.04)\end{array}$ & & $\begin{array}{l}0.470 \\
(0.86)\end{array}$ \\
\hline$\Delta \ln$ Government spending ( $\%$ of GDP) & & $\begin{array}{l}1.196 * * * \\
(7.25)\end{array}$ & & $\begin{array}{l}1.216^{* * *} \\
(7.80)\end{array}$ & & $\begin{array}{l}1.211^{* * *} \\
(7.11)\end{array}$ \\
\hline Reunification dummy & & $\begin{array}{l}34.68 \\
(0.71)\end{array}$ & & & & \\
\hline Constant & $\begin{array}{r}-1.254 \\
(0.90) \\
\end{array}$ & $\begin{array}{l}-2.717 \\
(1.05) \\
\end{array}$ & $\begin{array}{r}-1.328 \\
(0.69) \\
\end{array}$ & $\begin{array}{l}-0.867 \\
(0.46) \\
\end{array}$ & $\begin{array}{r}-1.607 \\
(0.54) \\
\end{array}$ & $\begin{array}{r}-5.601 \\
(1.06) \\
\end{array}$ \\
\hline Observations & 61 & 61 & 61 & 61 & 61 & 61 \\
\hline R-squared & 0.001 & 0.531 & 0.002 & 0.540 & 0.016 & 0.535 \\
\hline
\end{tabular}

Notes: Absolute values of t-statistics in brackets; **/***: significant at the 5/1\% level. 
Table 7: Regression results. OLS estimator with robust standard errors.

Government ideology as measured by the CMP Left-Right scale.

Dependent variable: growth rate in military expenditure (in percent of GDP) in the 1951-2011 period

\begin{tabular}{|c|c|c|c|c|c|c|}
\hline & $(1)$ & $(2)$ & $(3)$ & $(4)$ & $(5)$ & $(6)$ \\
\hline Ideology - CMP (right-wing) & $\begin{array}{l}0.112 \\
(0.93)\end{array}$ & $\begin{array}{c}0.138 * * * \\
(3.65)\end{array}$ & $\begin{array}{l}0.189 \\
(1.05)\end{array}$ & $\begin{array}{c}0.164 * * * \\
(2.69)\end{array}$ & $\begin{array}{l}0.106 \\
(0.67)\end{array}$ & $\begin{array}{c}0.112 * * * \\
\quad(2.95)\end{array}$ \\
\hline Dummy 1970-1990 & & & $\begin{array}{l}1.379 \\
(0.58)\end{array}$ & $\begin{array}{l}0.333 \\
(0.15)\end{array}$ & & \\
\hline $\begin{array}{l}\text { Ideology - CMP (right-wing) * } \\
\quad \text { Dummy 1970-1990 }\end{array}$ & & & $\begin{array}{l}-0.216 \\
(1.17)\end{array}$ & $\begin{array}{l}-0.107 \\
(1.16)\end{array}$ & & \\
\hline Dummy 1991-2011 & & & & & $\begin{array}{l}-3.660 \\
(1.52)\end{array}$ & $\begin{array}{l}0.958 \\
(0.27)\end{array}$ \\
\hline $\begin{array}{l}\text { Ideology - CMP (right-wing) * } \\
\text { Dummy 1991-2011 }\end{array}$ & & & & & $\begin{array}{l}0.0885 \\
(0.49)\end{array}$ & $\begin{array}{r}0.0677 \\
(0.61)\end{array}$ \\
\hline$\Delta \ln$ Population & & $\begin{array}{l}-2.367 \\
(1.26)\end{array}$ & & $\begin{array}{c}-0.401 * * * \\
(3.07)\end{array}$ & & $\begin{array}{c}-0.371 * * \\
(2.08)\end{array}$ \\
\hline$\Delta \ln$ GDP per capita & & $\begin{array}{l}0.501 \\
(1.13)\end{array}$ & & $\begin{array}{l}0.354 \\
(0.80)\end{array}$ & & $\begin{array}{l}0.483 \\
(0.89)\end{array}$ \\
\hline$\Delta \ln$ Government spending ( $\%$ of GDP) & & $\begin{array}{l}1.216^{* * *} \\
(8.49)\end{array}$ & & $\begin{array}{c}1.185^{* * *} \\
(7.50)\end{array}$ & & $\begin{array}{c}1.215^{* * *} \\
(7.50)\end{array}$ \\
\hline Reunification dummy & & $\begin{array}{l}52.85 \\
(1.04)\end{array}$ & & & & \\
\hline Constant & $\begin{array}{c}-2.437 * \\
(1.80) \\
\end{array}$ & $\begin{array}{l}-4.323^{*} \\
(1.90) \\
\end{array}$ & $\begin{array}{l}-3.367 \\
(1.53) \\
\end{array}$ & $\begin{array}{c}-4.417 * \\
(1.92) \\
\end{array}$ & $\begin{array}{r}-1.406 \\
(0.70) \\
\end{array}$ & $\begin{array}{r}-5.340 \\
(1.28) \\
\end{array}$ \\
\hline Observations & 61 & 61 & 61 & 61 & 61 & 61 \\
\hline R-squared & 0.031 & 0.575 & 0.057 & 0.570 & 0.050 & 0.568 \\
\hline
\end{tabular}

Notes: Absolute values of t-statistics in brackets; */**/***: significant at the 10/5/1\% level. 
Table 8: Regression results. OLS estimator with robust standard errors.

Government ideology as measured by Support for International Peace and Support for Welfare (CMP data).

Dependent variable: growth rate in military expenditure (in percent of GDP) in the 1951-2011 period

\begin{tabular}{|c|c|c|c|c|c|c|}
\hline & $(1)$ & $(2)$ & (3) & $(4)$ & (5) & $(6)$ \\
\hline Ideology - CMP International Peace & $\begin{array}{l}0.703 \\
(0.77)\end{array}$ & $\begin{array}{l}0.337 \\
(0.76)\end{array}$ & $\begin{array}{l}1.049 \\
(0.59)\end{array}$ & $\begin{array}{c}0.0310 \\
(0.03)\end{array}$ & $\begin{array}{l}0.921 \\
(0.63)\end{array}$ & $\begin{array}{l}1.373 \\
(1.30)\end{array}$ \\
\hline Ideology - CMP Welfare & $\begin{array}{l}-0.232 \\
(0.60)\end{array}$ & $\begin{array}{l}-0.411^{*} \\
(1.75)\end{array}$ & $\begin{array}{l}-0.413 \\
(0.76)\end{array}$ & $\begin{array}{l}-0.395 \\
(1.41)\end{array}$ & $\begin{array}{l}-0.236 \\
(0.27)\end{array}$ & $\begin{array}{l}-0.100 \\
(0.19)\end{array}$ \\
\hline Dummy 1970-1990 & & & $\begin{array}{l}-4.808 \\
(0.70)\end{array}$ & $\begin{array}{l}-1.332 \\
(0.22)\end{array}$ & & \\
\hline $\begin{array}{l}\text { Ideology - CMP International Peace * } \\
\quad \text { Dummy 1970-1990 }\end{array}$ & & & $\begin{array}{l}-0.660 \\
(0.36)\end{array}$ & $\begin{array}{l}0.448 \\
(0.36)\end{array}$ & & \\
\hline $\begin{array}{l}\text { Ideology - CMP Welfare * } \\
\text { Dummy 1970-1990 }\end{array}$ & & & $\begin{array}{l}0.537 \\
(0.85)\end{array}$ & $\begin{array}{c}0.0260 \\
(0.07)\end{array}$ & & \\
\hline Dummy 1991-2011 & & & & & $\begin{array}{r}-0.161 \\
(0.01)\end{array}$ & $\begin{array}{l}9.458 \\
(0.79)\end{array}$ \\
\hline $\begin{array}{l}\text { Ideology - CMP International Peace * } \\
\text { Dummy 1991-2011 }\end{array}$ & & & & & $\begin{array}{l}-6.055^{* * *} \\
\quad(3.23)\end{array}$ & $\begin{array}{l}-7.432 * * * \\
\quad(3.59)\end{array}$ \\
\hline $\begin{array}{l}\text { Ideology - CMP Welfare * } \\
\text { Dummy 1991-2011 }\end{array}$ & & & & & $\begin{array}{l}0.718 \\
(0.80)\end{array}$ & $\begin{array}{l}0.574 \\
(0.93)\end{array}$ \\
\hline$\Delta \ln$ Population & & $\begin{array}{l}-2.296 \\
(1.22)\end{array}$ & & $\begin{array}{c}-0.443^{*} \\
(1.98)\end{array}$ & & $\begin{array}{c}-0.0604 \\
(0.31)\end{array}$ \\
\hline$\Delta \ln$ GDP per capita & & $\begin{array}{l}0.471 \\
(0.97)\end{array}$ & & $\begin{array}{l}0.400 \\
(0.77)\end{array}$ & & $\begin{array}{l}0.635 \\
(1.15)\end{array}$ \\
\hline$\Delta \ln$ Government spending ( $\%$ of GDP) & & $\begin{array}{l}1.210 * * * \\
(8.13)\end{array}$ & & $\begin{array}{l}1.202 * * * \\
(7.22)\end{array}$ & & $\begin{array}{l}1.254 * * * \\
(8.12)\end{array}$ \\
\hline Reunification dummy & & $\begin{array}{l}49.12 \\
(0.97)\end{array}$ & & & & \\
\hline Constant & $\begin{array}{l}-1.306 \\
(0.33) \\
\end{array}$ & $\begin{array}{l}0.111 \\
(0.05) \\
\end{array}$ & $\begin{array}{l}-0.367 \\
(0.09) \\
\end{array}$ & $\begin{array}{l}0.298 \\
(0.10) \\
\end{array}$ & $\begin{array}{l}-1.536 \\
(0.10) \\
\end{array}$ & $\begin{array}{l}-10.19 \\
(0.83) \\
\end{array}$ \\
\hline Observations & 61 & 61 & 61 & 61 & 61 & 61 \\
\hline R-squared & 0.016 & 0.552 & 0.025 & 0.544 & 0.071 & 0.603 \\
\hline
\end{tabular}

Notes: Absolute values of t-statistics in brackets; */***: significant at the 10/1\% level. 